\title{
The difference of tensile bond strength between total etch and self etch dentin bonding on dentin surface
}

\author{
Adioro Soetojo \\ Department of Conservative Dentistry \\ Faculty of Dentistry Airlangga University \\ Surabaya - Indonesia
}

\begin{abstract}
Total etch dentin bonding agents had been used extensively in operative dentistry. These materials were used on dentin surfaces before application of the resin adhesive restorative. The purpose of this research was to prove the difference of tensile bond strength between total etch and self etch dentin bonding agent on dentin surface. The manner of preparing total etch dentin bonding agent was : bovine dentin as sample was grounded to give flat surface which was then etched with 37\% phosphoric acid for 15 seconds, washed with $20 \mathrm{ml}$ water and dried with blot dry technique. Sample was placed in a desiccator for one hour $60 \%$ humidity covered with bonding agent and put into tensile tool plunger and stored at room temperature $\left( \pm 28^{\circ} \mathrm{C}\right)$ for 24 hours. Sample was tested using Autograph instrument. The manner of preparing self etch dentin bonding was equal with total etch manner but without acid etching, washing and drying. The data analyzed using One-Way ANOVA test at $\alpha=0.05$ and followed Tukey HSD test. The result indicated that the tensile bond strength of total etch was higher than self etch dentin bonding at $60 \%$ humidity $(p \leq 0.05)$. In conclusion, the total etch dentin bonding agent with acetone solvents have a higher tensile bond strength compared with self etch dentin bonding agent also with dentin bonding in alcohol solvents.
\end{abstract}

Key words: total etch technique, self etch primer, tensile bond strength, dentin collagen, blot dry technique

Correspondence: Adioro Soetojo, c/o: Bagian Ilmu Konservasi Gigi, Fakultas Kedokteran Gigi Universitas Airlangga. Jln. Mayjend. Prof. Dr. Moestopo no. 47 Surabaya 60132, Indonesia.

\section{INTRODUCTION}

In recent years dentin bonding agent is extensively used in conservative dentistry, especially for class $\mathrm{V}$ erosive lesion restoration involving dentin tissue. Dentin bonding adhesive agent on dentin part (mainly collagen fibril tissue) can be in the form of chemical or physical-mechanical binding. ${ }^{1,2,3}$ The chemical binding is due to the interaction between amino collagen and carbonyl dentin bonding which would form amide (peptide) binding. The occurrence of physical-mechanical binding is due to penetration of bonding agent into nano space interfibriler and eventually bonding resin would polymerize to form mechanical retention, in addition physical bonding occures because of Vander Walls tensile bond between both agents. ${ }^{4,5,6}$

To reach maximal bending between dentin bonding material and dentin collagen, it is important that collagen fibril should be in permeable condition/active. ${ }^{1,7}$ Permeable collagen fibril is strongly influenced by the moist surrounding dentin surface. Some studies reported that the optimal humidity that enables collagen to be permeable is moist condition not wet or dry condition. If the condition surrounding the dentin is wet, bonding resin will be difficult to penetrate into collagen tissue because it is obstructed by water molecule. If the condition is too dry collagen fibril will collapse, as a result dentin bonding cannot bond the collagen. ${ }^{1,8}$
In recent years primer self etch dentin bonding has been extensively used. Resin has been added by acid etching, therefore in clinical application resin is really practical, because etching, washing and drying stage are not necessarily done. Since washing stage is not done consequently residual material would be left on dentin surface such as : salt which is resulting from the reaction between acid and hydroxy-apatite dentin, smear layer, denatured protein/collagen and bacteria. In certain period of time, those materials would infiltrate into the pulp which can cause pulp inflammation. ${ }^{9-12}$ The other character of self etch dentin bonding is to absorb more water comparing with total etch dentin bonding. The tensile bond strength is lower than total etch dentin bonding. ${ }^{13}$

Low viscosity of dentin bonding agent which has good wetting capacity would increase the energy of dentin surface. ${ }^{1,2}$ HEMA bonding agent (hydroxyethyl methacrylate) functions as hydrophilic moisturizer (hydrophilic humectants agent). ${ }^{14}$ The first time HEMA bonding agent was used as an agent increasing adhesive restoration in dentin to improve adaptation between both surfaces. ${ }^{15}$ On this study, $60 \%$ humidity was used due to the most optimal tensile bond strength of dentin bonding agent located on dentin surface. ${ }^{16}$

The aim of the study was to know the difference of tensile bond strength between total etch and self etch dentin bonding agent on dentin surfaces. 


\section{MATERIAL AND METHODS}

Bovine's incisivus teeth was taken from slaughtery house of Pegirian, Surabaya. Total etch dentin bonding agents were: Voco (Germany), Excite (Ivoclar-Vivadent, Schaan/Leichtenstein). Self etch dentin bonding agents were: Xeno (Dentsply De Trey GmbH, Germany), Clearfil Liner Bond 2 (Kuraray, Japan). Hard gypsum (Glass tone 2000, Dentsply, Germany). Adhesive tape (Indonesia). Liquid of acid etching (Ivoclar-Vivadent), self curing acrylic: vertex (Dentimex, Holland). The composition of the four dentin bonding agents is shown on Table 1.

Table 1. Dentin bonding agent composition

\begin{tabular}{lc}
\hline \multicolumn{1}{c}{ Material } & Composition \\
\hline Voco (total etch I) & $\begin{array}{c}\text { Bis-GMA, HEMA, butylated } \\
\text { hydroxyl toluene (BHT), } \\
\text { acetone, organic acid }\end{array}$ \\
Excite (total etch II) & HEMA, dimethacrylate, \\
& phosphoric acid, acrylate, \\
& silicon dioxide, alcohol \\
Xeno (self etch I) & Tetra-methacrylate-ethyl- \\
& pyro-phosphate \\
Clearfil Liner Bond 2 & $\mathrm{H}_{2} \mathrm{O}$, phenyl-P, 5-NMSA, \\
(self etch II) & ETOH/HEMA \\
\hline
\end{tabular}

The support tools: diamond disk, diamond drill, grease paper no. 400 and no 100 (Fuji Star, Japan), desiccator with vacuum valve (China), Hygrometer (Haar, Synth. Hygro, Germany) compressor/air suction (Schuco, USA), spuit injection, autograph AG-10 TE (Shimadzu, Japan), Plunger made of metal.

The treated tooth was carefully and accurately washed using brush and sharp scalpel for soft an hard tissue. During the washing process, the tooth was in wet condition. Further, the tooth was cut using diamond disk and planted in dental stone. The dentin part was placed upward and prepared using fissure form diamond drill. Dentin surface was fined using silicon grease paper no. 400 and continued no. 1000 . Then, dentin was covered by adhesive tape with $3 \mathrm{~mm}$ holes and attached in the middle of dentin surface. Dentin was polished once using cotton pellets for 15 minutes, next, it was washed using $20 \mathrm{cc}$ aquades from injection syringe and dried by cotton pellets. This drying procedure is called blot dry technique. The next step, the tooth was put into desiccator for one hour with $60 \%$ humidity by filling $150 \mathrm{cc}$ water into desiccator and put into hygrometer which has been calibrated. In this condition hygrometer showed the humidity was between $94-95 \%$. The air was pumped out using air suction from the valve on desiccator and the humidity reached $60 \%$. To save the time, active silica gel was filled into desiccator and the samples were ready to be treated.

The procedure was done for total etch dentin bonding sample was to remove sample from desiccator, polished by primer solvent and bonding mixture. Dentin surface was polished by disposable brush and left it dry for 30 seconds and lighting was done using light curing unit for 20 seconds (according to manufacture reference). Every control sample was put into cylinder and placed into the plunger. The opposite plunger was filled with self cured acrylic as restoration on dentin bonding with plastic filling instrument acrylic mixtured was put into plunger hole connected with opposite plunger and fixed by lock peg. Then, sample was kept at room temperature $\left( \pm 28^{\circ} \mathrm{C}\right)$ for 24 hours. (according to manufacture reference).

The procedure of self etch dentin bonding sample was almost the same with total etch dentin bonding without etching, washing or drying after the sample was removed from desiccator, dentin surface was polished with dentin bonding, lighting with light curing for 20 seconds (according to manufacture reference). The next step was: to perform tensile bond strength test using Autograph with cross head speed $=10 \mathrm{~mm} /$ minute, range $=5$, load cell capacity $=5 \mathrm{KN} / 500 \mathrm{kgf}$. Surface width of control dentin $=7,1 \mathrm{~mm}^{2}$. The collected data was analyzed using One-Way ANOVA test.

\section{RESULT}

The mean and standard deviation of tensile bond strength between total etch and self etch could be shown on Table 2.

Table 2. Tensile bond strength of total etch and self etch bonding agent on dentin surface (MPa)

\begin{tabular}{llr}
\hline \multicolumn{1}{c}{ Material } & N & $\overline{\mathrm{X}}$ and SD \\
\hline Total etch I & 8 & $16.67 \pm 1.99$ \\
Total etch II & 8 & $13.10 \pm 2.05$ \\
Self etch I & 8 & $10.97 \pm 1.67$ \\
Self etch II & 8 & $10.77 \pm 2.12$ \\
\hline
\end{tabular}

Note: $\overline{\mathrm{X}}=$ Mean of tensile bond strength, $\mathrm{SD}=$ Standard deviation, $\mathrm{N}=$ Number of samples

On table 2 data analysis was done by KolmogorovSmirnov test to achieve data normality. The result was: $p=0.580(p>0.05)$ for total etch I, $p=0.677(p>0.05)$, total etch II $\mathrm{p}=0.795(\mathrm{p}>0.05)$ self etch I and $\mathrm{p}=0.756$ $(p>0.05)$ self etch II. The table shows that all control groups have normal distribution.

Meanwhile, Levene test was done to prove that the data was homogenous. The result showed that all control groups have $p=0.905(p>0.05)$. It is means that four bonding agents of control groups are homogeneous.

Statistical analysis using ANOVA Test was performed to know whether there is difference of tensile bond strength among the four control groups. The result showed significant value of the four boding agents was 0.001 $(p<0.05)$ and it showed that significant difference was 
found among the four groups. Test Tukey-HSD was done to know the difference in every group and the result was shown on Table 3.

Table 3. The result of LSD test on total etch and self etch dentin bonding

\begin{tabular}{clc}
\hline Material & & Significant \\
\hline Total etch I & total etch II & $0.006^{*}$ \\
& self etch I & $0.001^{*}$ \\
\multirow{3}{*}{ Total etch II } & self etch II & $0.001^{*}$ \\
& total etch I & $0.006^{*}$ \\
& self etch I & 0.160 \\
Total etch I & self etch II & 0.109 \\
& total etch I & $0.000^{*}$ \\
Total etch II & self etch II & 0.160 \\
& self etch II & 0.997 \\
& sotal etch I & $0.000^{*}$ \\
& self etch II & 0.109 \\
\hline
\end{tabular}

Note: there is significant difference $\alpha=0.05$

Table 3 shows significant difference of tensile bond strength comparing total etch I with total etch II. Self etch II $(p<0.05)$. There is no significant difference $(p>0.05)$ of tensile bond strength comparing total etch II with self etch I and self etch II, even though tensile bond strength of total etch II is higher than self etch I and self etch II (Table 2).

\section{DISCUSSION}

Maximal adherence of dentin bonding agent in collagen occurs because collagen fibril is in permeable condition/ active has been proved. ${ }^{1,17}$ Permeable condition is possible if the environment surrounding dentin is moist but not dry or wet. If the environment is dry, collagen would collapse as a result amino collagen group is covered by the remain of fibril and further result carbonyl group in dentin bonding cannot chemically bind to amino collagen. Physically, nano space inter fibriler disappears because every collagen fibril would closely contact each other, so, dentin bonding is unable to enter into nano space forming mechanical retention. If the environment surrounding dentin is wet dentin bonding is not capable to bind either chemically or mechanically collagen fibril due to the excessive water molecule surrounding dentin. ${ }^{7,10}$ The result of this study shows tensile bond strength of total etch I has the highest significant value (16.67 $\mathrm{MPa}$ ) comparing to total etch II, self etch I and self etch II because total etch I is dentin bonding with acetone solvent. Acetone is volatile agent and capable of depleting therefore the viscosity will decrease. ${ }^{18}$ When total etch I is polished on dentin surface, it will penetrate into inter fibrile nano space, then, chase the water molecule and finally it will evaporate. In this way it will let resin bonding bind fibril collagen. The capability of acetone to chase water molecule is called water chasing effect. Chemically, acetone will not chase but bind water molecule then acetone as well as water will simultaneously evaporate.

Total etch II dentin bonding with alcohol solvents which does not evaporate as fast as acetone. Therefore during the evaporation the remain of water surrounding collagen will obstruct dentin bonding to interact with collagen. Acetone concentration will influence the thickness of resin bonding layer and tensile bond strength. Resin thickness does not correlate with tensile bond strength. The occurrence of resin crack is due to bad resin bonding polymerization and low resin strain (it is caused by excessive acetone amount). The other character of acetone is capable to increase vapour pressure of water especially water surrounding collagen. The ideal acetone concentration is $37 \%$ which can produce $30.2 \mu \mathrm{m}$ thickness of resin bonding layer.

The comparison between total etch and self etch resin bonding shows that tensile bond strength of total etch I dentin bonding is significantly higher than self etch I and self etch II $(\mathrm{p}<0.05)$. The result of this study is similar to the result of previous study reported that the remain of self etch dentin bounding procedure were not done and the remain would disturb adhesion mechanism of resin and dentin. ${ }^{13}$ Significant difference of total etch II tensile bond strength $(p>0.05)$ was not found comparing with self etch I and self etch II resin bonding, because total etch II with alcohol solvent which has slow vaporizing capacity, therefore, penetration into collagen fibril was also slow, so, it made adhesive strength low. In the process of dentin bonding adhesion in collagen, the competition of water molecule and resin bonding agent with collagen fibril occurred, therefore, water concentration surrounding dentin would determine the tensile strength. Mechanical bonding is a process of strong adhesion of one substance and the other which it could be reached through mechanical bounding or refention. ${ }^{1}$ In general, the adhesion is better than tensile bond strength among molecules. For example: in dentistry: Penetration of adhesive resin agent into macroscopic irregularities of a surface (porous, micro space, crack). Low concentration or semiviscus of adhesive resin is good material for this procedure because of great penetration capability. Cementation of gold crown, inlay, onlay, post endodontic and metal core also is mechanical bonding.

To achieve adhesion, both of interfaces should have tensile bond activity. ${ }^{1,2}$ It is also reported that this condition could occur without paying attention to the phase of the substance, whether it is solid, liquid or gas agent, with exception that adhesion between two kinds of gas is difficult to occur because lack of characters between the interfaces. The energy on the outer surface of solid material generally is bigger than the energy of the inner part due to molecular geometric lattice pattern. Inner molecular lattice of the entire atom has equal tensile bond and equal atom's distance therefore, the energy is minimal. On the surface of molecular lattice, the energy increases because the most distant atom has no equal tensile bond. The increasing 
energy of every unit area on the surface correlates with surface energy or surface tensile.

Adhering or attaching surface of two solid materials is very difficult ${ }^{1,4,5}$ even though without microscopic sight the surface is smooth, however, it is very rough in microscopically level. Therefore, if the two solid materials are adhered the adhesive contact would only occur on the rough part of the surface. As a whole, surface contact area is only small part, the adhesive strength is low. The tensile bond between two molecules would occur if the distance of both molecules is less than $0.7 \mathrm{~nm}$ consequently if the distance is higher than $0.7 \mathrm{~nm}$ tensile bond would be difficult to occur. One of the methods to manage the problem is by adding liquid material to the surface to achieve good adhesion in condition that the liquid is able perfectly to flow and to wet the surface. In operative dentistry, wetting capability of adhesive material on the surface would be deter mined by the cleanness of material surface, thin oxidation layer on metal surface could obstruct adhesive process including organic liquid. Acid etching on dentin surface could increase wetting and surface roughness resulting the opening of dentin tubules. ${ }^{19}$ The ability of adhesive surface material could be considered by the contact angle between adhesive liquid on the solid surface in interface area. ${ }^{1,2}$ If the adhesive molecule could perfectly bind the molecule of material which would be adhered consequently adhesive liquid would wet the whole surface, therefore wetting contact angle is $0^{\circ}$, but if the contact Angle is big, meaning that the wetting capability of adhesive material is bad.

The conclusion of this study is the tensile bond strength of total etch dentin bonding is higher compared with self etch dentin bonding.

\section{REFERENCES}

1. Anusavice KJ. Phillip's science of dental materials. $11^{\text {th }}$ ed. Philadelphia: WB Saunders Co; 2003. p. 21-395.

2. Craig RG, Powers JM, Wataha JC. Dental materials. Properties and Manipulation. $8^{\text {th }}$ ed. Baltimore, Boston, Carlsbad: Mosby Inc; 2002. p. $57-78$.
3. Noort RV. Introduction to dental materials. $2^{\text {nd }}$ ed. Edinburgh, London, New York, Oxford: CV Mosby Co; 2002. p. 11-78

4. Brackett MG, Brackett WW, Haish LD. Microleakage of class V resin composites placed using self-etching resins. Quintess Int 2006; 37:109-13.

5. Jacques $P$, Hebling J. Effect of dentin conditioners on the micro tensile bond strength of a conventional and a self-etching primer adhesive systems. Dent Mat 2005; 21:103-9.

6. Carrilho MR, Tay FR., Pashley DH. Mechanical stability of resindentin bonding components. Dent Mat 2005; 232-41.

7. Nakabayashi NP. Pashley DH. Hybridization of dental hard tissues. $1^{\text {st }}$ ed. Chicago IL: Quintess Publ Co, Ltd; 1998. p. 1-107.

8. Chiba Y, Miyasaki M, Rikuta A, Moore BK. Influence of environmental conditions on dentin bond strength of one application adhesive systems. Oper Dent 2004; 29:554-9.

9. Accorinte MLR, Loquercio AD, Reis A, Muench A. Adverse effect of human pulps after direct pulp-capping with the different components from a total etch, three step adhesive system. Dent Mat 2005; 21:599-607.

10. Frankenberger R, Tay FR. Self etch vs etch-and-rinse adhesive: effect of thermo-mechanical fatigue loading on marginal quality of bonded resin composite restorations. Dent Mat 2005; 21:397-412.

11. Zohairy AA, De Gee AJ, Mohsen M. Effect of conditioning time of self-etching primers on dentin bond strength of three adhesive resin cements. Dent Mat 2005; 21:83-93.

12. Perdigao J, Lopes M. The effect of etching time on dentin demineralization. Restorative Dent 2001; 32:19-26.

13. Moll K, Park HJ, Haller B. Bond strength of adhesive/composite combinations to dentin involving total and etch adhesive. J Adhesive Dent 2002; 3:171-80.

14. Leal JIR, Osorio R, Terriza JAH. Dentin wetting by four adhesive system. Dent Mat 2001; 17:526-32.

15. Xu J, Stangel I, Butler IS, Gilson DFR. An FT Raman Spectroscopy investigation of dentin and collagen surface modified by HEMA. J Dent Res 1997; 76:596-601.

16. Soetojo A. Kekuatan perlekatan antara bahan bonding HEMA dengan kolagen dentin pada bebagai kelembaban. Dissertation. Surabaya: Airlangga University; 2006. p. 66-9.

17. Summitt JB, Robbins JW, Hilton TJ, Schwartz R. Fundamentals of operative dentistry. $3^{\text {rd }}$ ed. Chicago: Quintess Publ Co, Inc; 2006. p. 183-242.

18. Cho BH, Dickens SH. Effect of the acetone content of single solution dentin bonding agents on the adhesive layer thickness and the microtensile bond strength. Dent Mat 2004; 20:107-15.

19. Rosales JI, Marshall GW, Watanabe LG. Acid etching and hydration influence on dentin roughness and wettability. J Dent Res 1999; 78:1554-9. 